\title{
Risk Sharing and Firm Size: Theory and International Evidence*
}

\author{
Mariassunta Giannetti ${ }^{\dagger}$
}

September 17, 2001

\begin{abstract}
This paper investigates the relation between financial development and firm size. The model shows that the quality of laws, by affecting the level of monitoring costs, has an effect on risk sharing and, through this channel, on the investor basis and the availability of external finance to firms. If, because of high monitoring costs, the provision of finance to projects is concentrated in very few individuals, the risk premium rises steeply with the amount of funds firms demand. As a consequence, in countries where the financial system does not favor risk sharing, the larger the optimal size of a firm would be, the higher is the cost of external finance; this limits firm size. Empirical evidence is also provided. The cost of debt is higher for firms demanding larger loans, even after controlling for leverage and other firm characteristics. Moreover, in countries where the financial system is less developed, financial constraints, indeed, appear more stringent for firms whose optimal size is larger.
\end{abstract}

Keywords: risk sharing, firm size, financial constraints, financial development

JEL Classification: G3, O16, L1

*Acknowledgments. I thank seminar participants at the Bank of Italy, Ente Einaudi, the Stockholm School of Economics (SITE), Universita' Cattolica of Milan, Universitat Pompeu Fabra, the CEPR Summer Symposium in Financial Markets in Gerzensee, 2001 SED, ESEM and EEA meetings and, especially, Guido Friebel Yrjo Koskinen, Steven Ongena, Patrik Säfvenblad, and Masako Ueda for comments. Of course, the usual disclaimer applies.

${ }^{\dagger}$ Dept. of Finance and SITE, Stockholm School of Economics, Sveavägen 65, Box 6501, S-113 83, Stockholm, Sweden. Phone. +46-8-736 9607 Fax. +46-8-31 64 22; Email: mariassunta.giannetti@hhs.se; Website: www.hhs.se/personal/giannetti 


\section{Introduction}

The literature on law and finance based on the influential papers of La Porta et al. (1997 and 1998) studies the effects of the quality of investor protection on the allocation and the cost of funds. It argues that managers and entrepreneurs can divert profits from outsider investors at a cost that increases in the level of investor protection and the fraction of equity owned by insiders. Consequently, if investor protection is poor, investors have an incentive to provide external funds only if the firm manager maintains a relatively high fraction of equity. Based on this argument, the literature has established a connection between weak institutions, insider ownership concentration and inefficiencies in the allocation of funds. ${ }^{1}$ The common conclusion is that in countries where diversion problems are more severe, distortions in investment decisions are more pronounced.

A less studied but complementary source of distortion in the allocation of investment consists in the underdiversification of investors and intermediaries' portfolios that, as diversion problems, may originate from lack of transparency and poor enforcement of law.

Indeed, there is evidence that problems of enforcement of financial contracts may limit risk sharing with possibly substantial consequences for investment decisions and business growth. The empirical evidence shows that credit cooperatives and peer monitoring within the local community can be essential to guarantee credit availability when there are severe problems of enforcement of financial contracts (Banerjee et al., 1994). This is true not only in countries with underdeveloped financial systems but also in advanced economies. Angelini et al. (1998) find evidence that cooperative banks easy access to credit for their members in Italy. Even US mutual fund managers overweight locally-headquartered firms in their portfolios (Coval and Moskowitz, 1999) because they seem to have an informa-

\footnotetext{
${ }^{1}$ See for instance La Porta et al. (1999), Shleifer and Wolfenzon (2000), Burkart and Panunzi (2001).
} 
tional advantage in evaluating nearby investments. Moreover, Guiso et al.(2001) show that household stock market participation is significantly larger in the US and UK than in Italy, where the rule of law is weaker. Finally it is well-known that as a result of market imperfections financial markets, which are the primary instrument for risk sharing, are undercapitalized where investor rights are poorly protected.

This empirical evidence suggests that lack of transparency, weak investor protection and poor enforcement of laws favouring fund provision at the local level may limit the number of investors who share business risk. The lack of risk sharing in turn may have sizeable effects on the cost of funds and investment decisions, which are worth studying.

This paper takes up these issue. It argues that the quality of investor protection influences the cost of investing in a firm, because the worse are the accounting standards and the financial laws and the poorer is their enforcement, the more difficult is to acquire firm level information and the more intense is the monitoring activity needed to appropriate the investment return. To a large extent, the financial resources and the effort needed to protect one's own rights and to enforce the contracts do not depend on the size of the investment. This creates a fixed cost in financing a new firm and, from the point of view of each investor, makes the return to investment to be positively correlated with its size. Consequently, even if there are benefits from diversification, investors find it optimal to fund only a few firms. In equilibrium, this determines among how many financiers business risk can be distributed: the larger are the fixed monitoring costs, the more concentrated are a firm's sources of finance. This has consequences on firm size, investment and the cost of funds. The fewer are the investors who directly or indirectly, through a financial intermediary, participate in financing a firm, the more their future wealth will be correlated with the firm's output. Consequently, the risk premium that risk averse investors demand to firms with growing demand for external funds is higher and firms find it optimal to expand less their assets. In equilibrium, firms invest less and remain smaller in financial systems with poor 
institutions because of the lack of risk sharing.

Besides providing an explanation for the real effects of the quality of laws complementary to the models based on cash flow diversion, the extent of risk sharing can also explain differences in the cost of debt which was neglected in the literature on law and finance until now.

Most importantly, the empirical implications of the model help to shed light on the relation between law, finance and industrial structure. The model predicts that, ceteris paribus, the firms with larger optimal scale must pay a higher risk premium, because they need a larger amount of funds. The empirical evidence supports this result. Indeed, firms in sectors where the demand for external funds is larger appear to be more financially constrained in countries where financial markets are less developed and there are less possibilities for risk sharing. In addition, there is evidence that the possibility of risk diversification influences the risk premium firms pay. In fact, the cost of debt is increasing in the absolute amount of financial liabilities of a firm, even after controlling for firm leverage and opaqueness. Not surprisingly, the scale of the loan matters especially in less financially developed countries.

The conclusion that the extent of risk sharing may affect the real activity has already been reached in different contexts. Saint-Paul (1992), Obstfeld (1994) and Acemoglu and Zilibotti (1997) show that the choice of the production function and the sectorial specialization may well depend on the extent of risk sharing possible within an economy. If investors can share risk without incurring in high monitoring costs, highly productive risky technologies are chosen and the economy growth rate is enhanced. In contrast, if investors cannot share risk, they must choose a low-productivity safe technology in order to smooth their consumption. This paper extends this argument by showing that the extent of risk sharing matters also at the firm level.

The remainder of the paper is organized as follows. Section 2 and 3 present the model and show how monitoring costs affect investment behavior. Section 4 and 5 present the empirical evidence and Section 6 concludes. 


\section{The model}

I study a model in which the quality of financial laws and the protection of investor rights by affecting the level of monitoring costs influences the economy's risk sharing and the allocation of capital. Monitoring costs that investors must spend to appropriate the return to investment affect firms' cost of capital, because they determine firms' investor basis. In this respect, the model is very similar to Merton (1987). However, it endogenizes how the set of firms which investors actually fund depends on the quality of investor protection and the financial institutions in a country. This has non-trivial implications because it allows to study the connection between institutions, risk sharing and investor basis and to make crosscountry predictions on the impact that firm characteristics, as the demand for external funds and firm optimal size, have on the cost of funds.

Moreover, I show that firms' efforts to become more visible to potential investors (such as advertising expenditures) are also influenced by the quality of institutions. In countries where investor protection is weaker and risk sharing is more limited, firms voluntarily choose to be more opaque and to remain unknown to most of potential investors.

\subsection{Investors}

There is a large number, $N$, of investors, who can be thought as individual investors who directly fund firms or as intermediaries. Investors maximizes the expected utility from their end-of-period wealth, $\widetilde{W}_{1}$, are identical and can allocate their initial wealth, $W_{0}$, among firms' assets which have a stochastic output and give a random return, $\widetilde{R}_{1}^{i}$, and a risk free asset with zero return. To appropriate the return from the investment in any firm $i$, investors must spend a fixed cost, $\tau .^{2}$ This may be thought as a monitoring cost that depends on the

\footnotetext{
${ }^{2}$ This means that if no monitoring cost is spent, the return to investment is zero.
} 
level of investor protection and enforcement of law: if institutions do not guarantee investor rights effectively, investors have to spend a larger amount of their resources to appropriate the return to their investment. ${ }^{3}$ Alternatively, $\tau$ may be interpreted as a cost necessary for gathering and processing information about the firms and that is inversely related to the quality of accounting standards in a country. As in Diamond (1984), monitoring is private and the information that is produced cannot be observed by outsiders. However, in contrast to in Diamond, I assume that an unique delegated monitor cannot arise, because the agents who act as intermediaries are subject to overload. ${ }^{4}$ To incorporate this effect in the model in the simplest possible way, I assume that, due to a time constraint, an intermediary cannot allocate an initial wealth larger than $W_{0}{ }^{5}$

Investors allocate their initial wealth, $W_{0}$, by solving the following portfolio allocation problem:

$$
\max _{k_{0}^{i} \geq \mathbf{0}, n} E_{\mathbf{0}} U\left(\widetilde{W}_{1}\right)
$$

where $\widetilde{W}_{1}=\sum_{i}\left(k_{0}^{i}\left(\widetilde{R}_{1}^{i}-1\right) d i+W_{0}-n \tau\right)$, subject to the constraint $\sum_{i} k_{0}^{i} d i \leq$ $W_{0}-n \tau$, which implies that agents cannot sell the risk free asset. The optimal portfolio allocation involves choosing how many firms, $n$, to finance and how much to invest in each firm $i, k_{0}^{i}$.

Investors are risk averse and therefore: $U^{\prime}>0$ and $U^{\prime \prime}<0$.

The portfolio problem is solved by maximizing the expected utility for different values of $n$ and by taking the value that maximizes the expected utility as the

\footnotetext{
${ }^{3}$ For instance, laws can make it easier to exercise voting rights for minority shareholders.

${ }^{4}$ This effect has been studied by Cerasi and Daltung (2000), who assume that the monitoring costs are increasing in the number of projects monitored by the intermediary and derive an optimal size of the bank which is bounded.

Alternatively, the intermediary can be thought as a coalition of agents each of whom agrees to monitor a firm and agree to share the output with all the remaining investors, as in Ramakrishnan and Thakor (1984). In this case, payoff pooling is inefficient if internal monitoring is costly.

${ }^{5}$ Alter natively, I could assume that at least an agent is needed to monitor a firm and that each coalition of agents is subject to internal monitoring costs.
} 
optimal number of firms funded by each investor $\left(n^{*}\right)$.

If firms returns are not perfectly correlated, investors could diversify risk by investing in a large number of firms. However, financing an extra firm involves a fixed cost, $\tau$, and, therefore, it may be optimal to fund only a subset of all the available firms and bear some diversifiable risk. Indeed, the empirical evidence, available especially for the US, shows that households hold stocks of very few firms in their portfolios (Guiso et al., 2000). This seems to be true to a different extent also for financial intermediaries as there is empirical evidence showing that US investment managers exhibit a strong preference for locally-headquartered firms (Coval and Moskowitz, 1999).

Investors may be thought to own shares and to appropriate of a fraction of the output proportional to their investment. It will be made clear later that the results would hold with any other form of financing, as long as the return depends on the state of the world. In particular, investors could finance firms with debt. If there is a positive probability of firm default, results are unchanged.

\subsection{Firms}

There is a large number of firms, $M$, which differ in their technologies. Technologies, in turn, are distinguished by the probability distribution of total factor productivity. I assume that there is a finite number of firm types, with a large number of firms of each type. The total factor productivity is identically and independently distributed across firms of the same type and is also independently (but not identically) distributed across firms of different types. These assumptions are central to the model because they guarantee that, as the number of firms of each type goes to infinity, agents could diversify all the risk by investing: in different firms. ${ }^{6}$ They are also well supported by the empirical evidence which shows that corporate growth rates are idiosyncratic (Davis and Haltiwanger, 1992;

\footnotetext{
${ }^{6}$ For the results of the model to hold I just need that the productivity shocks are not perfectly correlated across firms. The assumption that the shocks are independently distributed is done only for computational simplicity.
} 
Geroski, 1999). In fact, the evidence on tendency towards common growth rates across firms in the same industry is very weak and macroeconomic variables are not very useful to explain individual firms growth rates. It is, therefore, common to assume that firm specific uncertainty dominates firm level dynamics (see, for instance, Hopenhayn, 1992).

The production function of firm $i$ is:

$$
\widetilde{X}_{1}^{i}=\widetilde{A}_{1}^{i}\left(K_{0}^{i}\right)^{\alpha}
$$

where the random variable, $\widetilde{A}_{1}^{i}$, is the total factor productivity of firm $i, K_{0}^{i}$ is the capital invested in firm $i$ at $t=0$ and $\alpha$ is a technological parameter. The output, $\widetilde{X}_{1}^{i}$, which is realized at $t=1$ depends on the capital invested at $t=0$ and on the realization of the random productivity shock, which is unknown at $t=0$.

Firms produce an homogeneous output and, since there are decreasing returns to scale, several firms can operate in equilibrium.

In what follows, I will abstract from the possibility that firms can merge. This is equivalent to say that the above production function represents firms after all the incentives for corporate "internal" diversification have been exploited. Indeed, corporate diversification is unlikely to substitute financial markets, because there is evidence that the potential benefits are often offset by the costs due to agency problems and power struggles among divisions within the conglomerate (Rajan, Servaes and Zingales, 2000).

Firms are run by managers who maximize expected profits less investment expenditures. Managers can also exercise effort $m^{i}$ to increase a firm's visibility to potential investors by trying, for instance, to advertise the firm in financial newspapers. This advertising effort involves a cost in terms of the output, $c\left(m^{i}\right)$, for the manager, but can decrease the cost of funds, $\widetilde{R}_{1}^{i}$, since more visibility can increase a firm investor basis. I assume that the relation between advertising effort and the actual number of investor of a firm $i, \nu^{i}$, is the following. The number of potential financiers in the market is $N n^{*}$ (i.e. the number of investors times 
the number of share in their optimal portfolio). Firm $i$ 's expected number of financiers is $\frac{m^{i}}{\sum_{k} m^{k}} N n^{*}$ (or the closest integer). This means that firm $i$ will get a number of financiers that is proportional to the share of its advertising effort relative to the ones of all the firms which ask for funds.

The firm manager chooses how much effort to exercise to make the firm visible to potential investors and the amount of capital to be employed in the firm, $K_{\mathbf{0}}^{i}$.

The expected payoff of firm $i$ manager are:

$$
E_{0} \pi_{1}^{i}=E_{\mathbf{0}}\left[\widetilde{A}_{1}^{i}\left(K_{0}^{i}\right)^{\alpha}-\widetilde{R}_{1}^{i}\left(m^{i}\right) K_{\mathbf{0}}^{i}-c\left(m^{i}\right)\right]
$$

I assume that the cost of efforts $c\left(m^{i}\right)$ is increasing and convex. Therefore, $c^{\prime}\left(m^{i}\right)>0$ and $c^{\prime \prime}\left(m^{i}\right)>0$.

Before taking investment decisions, managers know only the distribution of total factor productivity, but not the realization of $\widetilde{A}_{1}^{i}$. They appropriate the profits net of financing and effort costs. For simplicity sake, I assume that they have no initial wealth. I will analyze later the implications of internal funds accumulation.

\subsection{The equilibrium}

To summarize, agents choose simultaneously the following quantities:

- Managers choose the effort to exercise to make their firm visible taking the aggregate effort, $\sum_{k} m^{k}$, as given and make investment decisions

- Investors choose in how many and which firms to invest and make portfolio decisions

An equilibrium of the above economy is an allocation and equilibrium returns that satisfies the following conditions:

1. Investors maximize utility taking the return to investment and other investors' decisions as given. 
2. After learning the expected value of its total factor productivity (but before knowing its actual value), the manager of firm $i$ maximizes the expected profits and announces the pair of aggregate investment in firm $i$ and return she can offer: $\left(K_{0}^{i}, \widetilde{R}_{1}^{i}\left(K_{0}^{i}\right)\right)$, where $K_{0}^{i}$ and $\widetilde{R}_{1}^{i}\left(K_{0}^{i}\right)$ solve the firm's profit maximization problem.

3. Managers optimally choose the effort to exercise to make their firm visible taking the aggregate effort, $\sum_{k} m^{k}$, as given

4. Total investment is less or equal to the initial wealth: $\sum_{i} K_{\mathbf{0}}^{i} \leq N W_{\mathbf{0}}$.

5. Demand of capital is equal to supply of capital for all firms of all types. This implies that the investment of the $\nu^{i}$ financiers of firm $i$ is equal to the aggregate investment in firm $i: \nu^{i} k_{0}^{i}=K_{0}^{i}$.

6. Investors are willing to fund a total number of firms which is equal to the total number of firm financiers: $N n^{*}=\sum_{i} \nu^{i}$

I study a symmetric equilibrium in which investors hold the same portfolios. From the assumptions of the model it also follows that firms with the same technological characteristics invest in the same amount and their managers exert the same effort.

A symmetric equilibrium exists if the following condition holds.

Remark 1. Existence of a symmetric equilibrium. Define $M_{k}$ the number of firms of type $k$. In an equilibrium in which investors have a symmetric portfolio the following condition must be satisfied: $\nu^{k} M_{k}=a N$, where a can be any integer greater than zero. This condition implies that each investor must be able to invest in the same number $a$ of firms of type $k$.

Note that such a condition can always be satisfied if the number of firms of type $k$ that enter in equilibrium is endogenized. However, here I disregard entry 
and assume that all the $\mathrm{M}$ firms are sufficiently productive and receive a positive amount of external funds in equilibrium.

\section{Equilibrium implications}

\subsection{Zero Monitoring Costs}

If $\tau$ were equal to zero, investors would invest in each firm at least a small amount of their wealth (i.e. $n^{*}=M$ ) In this case, if there is a large enough number of firms of each type, $M_{k} \rightarrow \infty$, risk can be perfectly diversified and the allocation of investment would be such that:

1. if $\sum_{i} K_{0}^{i^{*}}<N W_{0}, \bar{A}_{1}^{i}\left(K_{0}^{i^{*}}\right)^{\alpha-1}=1$ for any $i$

2. if $\sum_{i} K_{\mathbf{0}}^{i^{*}}>N W_{0}, \bar{A}_{1}^{i}\left(K_{\mathbf{0}}^{i^{*}}\right)^{\alpha-1}=\bar{A}_{1}^{j}\left(K_{\mathbf{0}}^{j^{*}}\right)^{\alpha-1}$ for any $i$ and $j$.

where $\left\{K_{\mathbf{0}}^{i^{*}}\right\}$ is the allocation of capital that solves the problem of maximization of the expected output.

In what follows I will refer to $K_{0}^{i^{*}}$ as the optimal scale of a firm of type $i{ }^{7}$

\subsection{Positive Monitoring Costs}

This section analyzes the properties of the equilibrium allocation with positive monitoring costs and shows that the level of monitoring costs influences firm size and the cost of funds.

To solve the model I first study the equilibrium in the market for funds for given $\nu^{i}$ and $n^{*}$ and then I analyze how their optimal value is influenced by the level of monitoring costs.

For any given value of $n$, the first order conditions of agents portfolio decisions are:

${ }^{7}$ Notice that this model, like Lucas (1978), predicts that, ceteris paribus, average firm size is larger in rich countries (where the initial wealth is larger). 


$$
E_{\mathbf{0}}\left[U^{\prime}\left(\widetilde{W}_{1}\right)\left(\widetilde{R}_{1}^{i}-1\right)\right]-\lambda=0
$$

where $\widetilde{W}_{1}=\sum_{i}\left(k_{0}^{i}\left(\widetilde{R}_{1}^{i}-1\right)+W_{0}-n \tau\right)$ and $\lambda$ is the multiplier associated with the constraint $\sum_{i} k_{0}^{i} d i \leq W_{0}-n \tau$. As usual, $\lambda>0$ only if the constraint is binding.

Since financing a firm involves a fixed cost, investors may find it optimal to fund only a subset of the available firms.

Equation 3.1 may be rewritten as:

$$
E_{0}\left(\widetilde{R}_{1}^{i}\right)=1+\frac{\lambda-\operatorname{Cov}\left(U^{\prime}\left(\widetilde{W}_{1}\right), \widetilde{R}_{1}^{i}\right)}{E_{t}\left(U^{\prime}\left(\widetilde{W}_{1}\right)\right)} .
$$

The equilibrium risk premium for investing in any firm $i$ depends on the covariance between the marginal utility of the final wealth and the return to investment of this firm, which is obviously negative under my assumptions on $\widetilde{A}_{1}$. The absolute value of the covariance depends on the size of the investment in the firm: the larger this is, the more the return of firm $i$ is correlated with the final wealth. This is proved in the next proposition.

Proposition 3.1 (Risk premium and investment size). The equilibrium risk premium of firm $i$ increases in the size of the investment of each investor in firm $i$.

Proof. See appendix.

It is important to note that Proposition 3.1 does not depends on any particular form of financing. Although the most direct interpretation is that investors fund firms with equity and that the lack of risk sharing influences the equity premium, all the results would go through if firms issued debt and had a positive probability of default. In fact, also in this case the covariance between the return to investment 
and the final wealth would be positive and the cost of external funds would depend on the firm's investor basis.

The demand for funds is derived from the profit maximization first order conditions.Firm managers maximize profits and take into account the effect of of size of the investment on the risk premium. The profit maximizing conditions implies that, from the point of view of the investors, a firm return depends negatively on aggregate investment in firm $i, K_{0}^{i}$. The first order condition for the optimal investment of firm $i$ is the fpllowing:

$E_{\mathbf{0}}\left(\widetilde{R}_{1}^{i}\right)=\frac{1}{2}\left(\alpha \bar{A}_{1}^{i}\left(K_{0}^{i}\right)^{\alpha-1}+1+\frac{\lambda}{U^{\prime}\left(\bar{W}_{1}\right)}\right)=\frac{1}{2}\left(\alpha \bar{A}_{1}^{i}\left(\nu^{i} k_{0}^{i}\right)^{\alpha-1}+1+\frac{\lambda}{U^{\prime}\left(\bar{W}_{1}\right)}\right)$

The continuity between $1+\frac{\lambda}{U^{\prime}\left(\bar{W}_{1}\right)}$ and infinity of the expected return in the aggregate investment in firm $i, E_{0}\left(\widetilde{R}_{1}^{i}\right)$, guarantees the existence of an equilibrium. In fact, taking the choices of other investors as given, the demand for funds of firm $i$ is monotonic decreasing and continuous between infinity and $1+\frac{\lambda}{U^{\prime}\left(\bar{W}_{1}\right)}$, while the supply of funds is monotonic increasing; as has been shown in the appendix. Therefore, an intersection point can always be found for any combination of individual choices.

In the proof of Proposition 3.1 it has been shown that the linearized form of the supply of external funds to firm $i$ is:

$$
E_{0}\left(\widetilde{R}_{1}^{i}\right)=1+\frac{\lambda}{U^{\prime}\left(\bar{W}_{1}\right)}-\frac{U^{\prime \prime}\left(\bar{W}_{1}\right)}{U^{\prime}\left(\bar{W}_{1}\right)} k_{0}^{i} V\left(\widetilde{R}_{1}^{i}\right)
$$

Equation 3.4 is the upward sloping supply for funds of firm $i$, for a given number $\nu^{i}$ of financiers. From equation 3.3, it is obvious that the effect of an increase in the number of financiers, $\nu^{i}$, is to decrease the demand for funds to each investor and therefore has the effect of decreasing the firm's cost of funds. In particular if $\nu^{i}=N$ and $M_{k} \rightarrow \infty$, no risk premium is required, because 
$\operatorname{Cov}\left(U^{\prime}\left(\widetilde{W}_{1}\right), \widetilde{R}_{1}^{i}\right) \rightarrow 0$

Therefore, the equilibrium ultimately depends on $\nu^{i}$, which in turn is determined by managers advertising efforts, $\mathrm{m}^{i}$, and the optimal number of assets in investors portfolios, $n^{*}$.

When making portfolio decisions, investors choose the number and which firms they wish to fund, $n^{*}$, in order to maximize their expected utility. Their choice depends on the level of monitoring costs, as is proved in Proposition 3.2.

Proposition 3.2 (Monitoring costs and the size of investment). If monitoring costs, $\tau$, decrease, the risk premium decreases for all the firm types, if the coefficient of absolute risk aversion is decreasing in the level of final wealth. Furthermore, it may become optimal for consumers to finance a larger number of firms. In this case, the equilibrium cost of capital decreases under more general conditions.

Proof. A decrease in the level of monitoring costs can determine two possible effects. First of all, there is always a wealth effect. When monitoring costs decrease, a larger amount of the initial wealth can be invested in the firms which are currently funded. The effect of this is to decrease the equilibrium risk premium for all firms, as long as the coefficient of absolute risk aversion $-\frac{U^{\prime \prime}}{U^{\prime}}$ is decreasing. This follows from the linearized form of the supply of capital to firm $i$ (equation 3.4). In fact, for given demand of capital by firm $i$, the equilibrium investment increases as long as the slope of the supply of capital decreases. Under the above condition, the equilibrium rate of return decreases for all firms.

However, also another effect can be at work. If $\tau$ decreases the cost of investing: in an additional firm goes down and, therefore, it may be optimal to increase the number of firms that are financed. This improves the diversification of the portfolio (diversification effect) of each investors, because the demand for funds by firm $i$ to each investor decreases. This decreases the risk premium firms pay in equilibrium on external funds under the more general condition that the coefficient of absolute risk aversion does not increase too fast in the individual wealth, if $\lambda=0$ (i.e. a 
positive amount of wealth is invested in the risk free asset). However, if $\lambda>0$, the marginal utility of wealth may increase and the increase in the intercept of equation 3.4 could counteract the decrease in the slope.

Finally, the way in which potential financiers are shared among the existing: firms depends on managers effort choices. Managers decide how much effort to exercise to advertise the firm among potential investors. To do so, they take into account that investors buy at most $N n^{*}$ shares and that $m^{i}$ affect the risk premium through the number of financiers.

The first order condition that determine the optimal level of expenditures in advertising can be written as follows to take into account that $\nu^{i}$ must be an integer:

$$
\begin{gathered}
\min _{m^{i}}-\frac{U^{\prime \prime}}{U^{\prime}} V\left(\widetilde{R}^{i}\right)\left(k_{0}^{i}\right)^{2} \frac{N n^{*}}{\sum_{k} m^{k}}-c^{\prime}\left(m^{i}\right) \\
\text { s.t. } \frac{m^{i}}{\sum_{k} m^{k}} N n^{*} \in\left\{0,1, \ldots, N n^{*}\right\} \\
-\frac{U^{\prime \prime}}{U^{\prime}} V\left(\widetilde{R}^{i}\right)\left(k_{0}^{i}\right)^{2} \frac{N n^{*}}{\sum_{k} m^{k}}-c^{\prime}\left(m^{i}\right)>0^{8}
\end{gathered}
$$

From the inspection of equation 3.5 and the convexity of $c\left(m^{i}\right)$, Proposition 3.3 follows.

Proposition 3.3 (Firm investor basis). In firms that invest more, managers exercise more effort to acquire visibility and therefore have a larger investor basis. However they also demand a large amount of funds to each single investor and therefore pay a larger risk premium. Moreover, when investors demand for

\footnotetext{
${ }^{8}$ The level of expenses must be such that $\nu^{i}$ is an integer. If when the first order condition is satisfied with the equality $\frac{m^{i}}{\sum_{k} m^{k}} N n^{*}$ is not an integer, the number that makes it equal to the closest smaller integer is taken.
} 
financial assets is low ( $N n^{*}$ low), it is optimal for firms to remain more opaque, as the optimal level of effort is lower.

In equilibrium, firms with larger demand for capital ask for more funds to any single investor, especially in countries where the monitoring costs are higher ( and therefore $n^{*}$ is low). Therefore, after controlling for the variability of returns, in equilibrium, firms with higher expected total factor productivity must provide a higher return to investment, because their demand for capital to each investor is larger for any level of the interest rate. Moreover, this risk premium is increasing in the level of monitoring costs.

Given the initial distribution of firms' technological characteristics, in countries where the sources of funds are more concentrated, firms with high expected total factor productivity invest less and therefore remain smaller.

From a dynamic point of view, firms that thanks to exogenous productivity improvements have positive growth opportunities but lack of internal funds react differently depending on their investor basis. The smaller this is, the more the risk premium increases when firms demand more external funds. In equilibrium, given a positive productivity shock, firms will expand less their assets in countries where the monitoring costs are larger.

For given technological conditions the model has also some implications for firm size distribution. Since high productivity firms that would have larger optimal scale are relatively more financially constrained in equilibrium in countries where monitoring costs are higher, the variance of the firm size distribution is expected to be smaller. However, if entry is considered, the implications of the model for firm size distribution become ambiguous. In fact, the model implies that for high values of the monitoring costs, it may not be optimal to fund firms whose optimal scale is very small. As a consequence, the lower are monitoring costs, the more firms with small optimal scale are expected to enter. Although in principle the effect of monitoring costs on cross-country average firm size may be ambiguous, Kumar et al. (1999) suggest that constraints that poor protection of investor 
rights imposes to firms with large optimal scale prevail on the effects of entry.

The model could be generalized to account that the effort costs of increasing a firm visibility may be heterogenous. In this case, the function $c\left(m^{i} ; \lambda^{i}\right)$ depends also on a parameter $\lambda^{i}$, which proxies for the access of the firm management to the media or to financial institutions in such a way that $c_{\lambda^{i}}<0$ and $c_{m^{i} \lambda^{i}}<0 .{ }^{9}$ Better access to the media or to financial institutions reduce the marginal cost of acquiring visibility and allows firms to increase more their investor basis. This implies that there may be equilibria in which firms with the same distribution of total factor productivity have a different number of financiers. In particular, a few firms may be allowed to invest more at lower cost, because of their larger investor basis, although they are not more productive. In this case, large firms which to some extent overinvest may coexist with smaller financing constrained firms. If there is a small number of firms $\left(x<n^{*}\right)$ with easier access to media that succeed in receiving funds by all the $N$ investors, the remaining firms have an even smaller investor basis (since $\nu_{i}<\frac{\left(n^{*}-x\right) N}{M-x}$ in this case) and therefore are even more financially constrained.

The existence of these large firms makes the distortion described in this paper even more relevant when one studies the determinants of the cost of funds and of financial constraints for small and medium size enterprises with low level of visibility. This is what I will do in the empirical analysis which relies on a sample of mostly private companies.

\subsection{Dynamic implications}

Until this point, I have considered a static model and did not allow managers to reinvest profits. However, if a stage is added to the model and risk neutral managers can reinvest the internal funds generated by the first period profits $\pi_{1}^{i}$, firms with the same expected productivity and investor basis can differ in the

\footnotetext{
${ }^{9}$ Djankov, McLiesh, Nenova and Shleifer (2001) show that such a situation may be very relevant, as private families who own the largest industrial firms own often also the media.
} 
amount of funds they demand to outside investors.

For simplicity, I assume that firms' investor basis remains equal and that the distribution of total factor productivity is invariant and independent across periods.

The optimal demand for external funds by firm $i$ in period 1 is now $K_{1}^{i}-\pi_{1}^{i}$. Of course, this implies that firms that have a positive productivity shock at $t=1$ have lower cost of funds and can increase investment. Proposition 3.4 shows that firms with higher expected productivity have higher cash-flow sensitivity of investment.

Proposition 3.4 (Cash-flow sensitivity and optimal firm size). Firms with higher expected total factor productivity and therefore larger optimal size increase investment relatively more following a given realization of profits relative to the initial investment, $\frac{\pi_{1}^{i}}{K_{0}^{i}}$.

Proof. The market clearing condition for any firm $i$ can be written as:

$$
\frac{1}{2}\left(\alpha \bar{A}_{2}^{i}\left(K_{1}^{i}\right)^{\alpha-1}+1+\frac{\lambda}{U^{\prime}\left(\bar{W}_{1}\right)}\right)=1+\frac{\lambda}{U^{\prime}\left(\bar{W}_{1}\right)}-\frac{U^{\prime \prime}\left(\bar{W}_{1}\right)}{U^{\prime}\left(\bar{W}_{1}\right)} \frac{K_{0}^{i}}{\nu^{i}}\left(\frac{K_{1}^{i}}{K_{0}^{i}}-\frac{\pi_{1}^{i}}{K_{0}^{i}}\right) V\left(\widetilde{R}_{1}^{i}\right)
$$

Taking the ratio of the market clearing conditions for any two firms 1 and 2 with $\bar{A}_{2}^{1}>\bar{A}_{2}^{2}$, I get:

$$
\frac{\bar{A}_{2}^{1}\left(K_{1}^{1}\right)^{\alpha-1}}{\bar{A}_{2}^{2}\left(K_{1}^{2}\right)^{\alpha-1}}=\frac{\frac{1}{2}\left(1+\frac{\lambda}{U^{\prime}\left(\bar{W}_{1}\right)}\right)-\frac{U^{\prime \prime}\left(\bar{W}_{1}\right)}{U^{\prime}\left(\bar{W}_{1}\right)} \frac{K_{0}^{1}}{\nu^{1}}\left(\frac{K_{1}^{1}}{K_{0}^{1}}-\frac{\pi}{K_{0}^{1}}\right) V\left(\widetilde{R}_{1}^{1}\right)}{\left.\frac{\lambda}{U^{\prime}\left(\bar{W}_{1}\right)}\right)-\frac{U^{\prime \prime}\left(\bar{W}_{1}\right)}{U^{\prime}\left(\bar{W}_{1}\right)} \frac{K_{0}^{2}}{\nu^{2}}\left(\frac{K_{1}^{2}}{K_{0}^{2}}-\frac{\pi}{K_{0}^{2}}\right) V\left(\widetilde{R}_{1}^{2}\right)}
$$

Since from Propositions 3.1 and $3.3 \mathrm{I}$ know that $\frac{K_{0}^{1}}{\nu^{1}}>\frac{K_{0}^{2}}{\nu^{2}}$, an equal increase in $\frac{\pi}{K_{0}^{1}}$ and $\frac{\pi}{K_{0}^{2}}$ decreases the right hand side of the above equation. The equality can be satisfied only if $K_{1}^{1}>K_{1}^{2}$, while $K_{1}^{2}>K_{1}^{1}$ would imply a contradiction. 
For given level of the expected productivity therefore firms that had a positive productivity shock invest more and this generates cash-flow sensitivity of investment. Investment increases for two reasons:

1. The demand for external funds is lower and for given investor basis this decreases the risk premium and therefore the cost of funds.

2. The opportunity cost of internal funds for the risk neutral firm manager is equal to the risk free asset return. ${ }^{10}$

Most importantly, the impact of internal funds on investment differs across firms. In fact, it is larger for firms with larger optimal scale, which are initially more financially constrained. Moreover, it is larger for firms with smaller investor basis and therefore in countries where there are less possibilities for risk sharing.

\section{Empirical Implications}

This section examines the empirical implications of the model and contrasts them with the empirical evidence provided by the existing literature.

In the model, because of the monitoring costs, households (or intermediaries) expose themselves to substantial diversifiable risk by financing only a small number of firms. Although there are no thorough cross-country comparisons of households' portfolio decisions because of the lack of comparable data, there is extensive evidence that weak protection of investor rights has an impact on the supply of funds and markets capitalization (La Porta et al., 1998), which is obviously very important for sharing business risk.

The counterpart of the lack of portfolio diversification in countries where the rules of law are weaker is the small investor basis of firms. Indeed, Himmelberg et

\footnotetext{
${ }^{10}$ There is indeed empirical evidence that entrepreneurs have a lower opportunity cost of funds in investing their private wealth in their own business (Moskowitz and Vissing-Jorgensen, 2001). This could be given to lower risk aversion (as I assume here) or to the fact that they enjoy private benefits from running their own business.
} 
al. (2000) show that the weaker is legal protection, the more likely is to observe concentrated inside equity ownership of firms. Moreover, since in countries where investor protection is poor the bond markets are also underdeveloped, firms have limited scope to enlarge their investor basis through the emission of bonds. However, there is evidence that firms try to increase their investor basis by increasing the number of bank relationships in countries where investor protection is weaker and the enforcement of law is poorer (Ongena and Smith, 2000). Anyway, the extent of risk sharing and, more in general, the availability of external funds that firms manage to achieve is likely to remain suboptimal, since several studies find significant effects of financial and institutional development on firm size, credit availability and the cost of funds. In fact, there is evidence that a lower protection of investor rights decreases corporate valuation and, therefore, increases the cost of external funds (La Porta et al., 1999). Furthermore, investor protection and the enforcement of law have a significant impact on average firm size (Kumar Rajan and Zingales, 1999).

Although the previous studies provide indirect empirical evidence compatible with the model, they are compatible also with alternative explanations. They are compatible for instance with Wolfenzon and Shleifer (2000), who show that in countries where outside shareholders are less protected by the laws and diversion problems are more severe, firm size should be smaller, because less funds can be raised through the stock market. ${ }^{11}$

In general, theories based on different financial imperfections have similar implications: financial imperfections make more difficult to raise funds and, as a consequence, firms remain smaller in less developed financial markets. However, the model presented in this paper allows to make more detailed empirical predictions on which categories of firms are likely to be more financially constrained and to pay a higher risk premium in equilibrium, if the lack of risk sharing plays

\footnotetext{
${ }^{11}$ Himmelberg et al. (2000), indeed, find that fir ms seem to be more financially constrained in countries where the ownership is more concentrated. Moreover, Love (2000) find that financing constraints are more stringent in less financially developed countries.
} 
a significant role in capital allocation.

On average, firms with larger demand for external capital are expected to be relatively more financially constrained in financial markets where investor rights are less protected if the lack of risk sharing is important. In fact, the covariance between the marginal utility of consumption and the return to investment increases in absolute value if the demand for funds goes up and consequently the equilibrium risk premium is higher. This is the more so, the fewer are the investors which fund a firm in equilibrium.

In conclusion, the absolute amount of external funds that firms demand is important here and not the share of capital that is retained by the firm manager, like in "diversion" models. Moreover, while the models based on diversion concern equity financing only, the implications of this model hold also for debt.

The following section illustrates an empirical strategy to evaluate whether the implications of the model are corroborated by the data.

\section{Empirical evidence}

The importance of risk sharing for firms' cost of external funds and investment behavior may be difficult to evaluate. In fact, if advertising costs are heterogeneous, because, for instance, firms have differential access to media, there may be firms with a large investor basis and access to funds at low cost, even in countries where monitoring costs are high. In order to have a sample of firms which is as homogeneous as possible in this respect, I rely on a sample of mostly private firms, which excludes the largest public companies in a country and, therefore, are likely to have the same possibilities to be visible. Moreover, these firms are unlikely to be able to recur to the international capital markets and therefore for them the imperfections of the domestic financial markets should be more important.

In what follows, I evaluate whether the amount of the funds firms demand to external financiers (both investors and intermediaries) has an impact on the cost of external funds and financing constraints. I also compare how the impact differs 
across financial systems according to the possibilities of risk sharing they offer.

The firm level data and the aggregate proxies, which measure the possibilities of risk sharing in an economy, are described below.

\subsection{Data}

Information on individual firms is taken from the Amadeus (Analyze Major Database from European Sources) Database by Bureau Van Dijk.

Amadeus provides balance sheet information for firms having minimal size requirements (sales greater than ten millions of Euros, more than 150 employees or total assets greater than 10 millions of Euros) beginning from 1993 to 1998 for 31 European countries. The sample collects information on about 225.000 firms. The panel, however, is very unbalanced and there are many missing observations. Therefore, I restrict the analysis to 11 European countries for which there is at least information on fixed assets and value added and the time dimension for the individual firms is sufficiently long to allow the estimation of investment equations, needed to have a measure of financing constraints. These are Austria, Belgium, Finland, France, Germany, Ireland, Italy, the Netherlands, Portugal, Spain and the UK. ${ }^{12}$

Although this data set allow to test the model with a large number of firms, there are some limitations. First of all, I cannot distinguish between bank loans and bonds and, since I have only balance sheet data, I have no information on bank relationships and the number of financing banks. Second, since the companies are mostly non-listed, I have only book values and the price of shares is obviously not available. Notwithstanding these limitations, I believe that this data set can provide precious information on private companies' behavior.

Table 5.1 and 5.2 provide some descriptive statistics on firm characteristics by country of incorporation and on the variables I use in the empirical analysis.

\footnotetext{
${ }^{12}$ For a more detailed description of the dataset, see Giannetti (2000).
} 
Table 5.1: Number of employees by country

The statistics are calculated using all the firms included in data set in 1994.

\begin{tabular}{cccc}
\hline & \# Firms & Median \# Employees & Standard Deviation \\
\hline Austria & 183 & 341 & 5062 \\
Belgium & 5328 & 47 & 1090 \\
Finland & 1269 & 71 & 461 \\
France & 9814 & 80 & 2516 \\
Germany & 2173 & 435 & 11965 \\
Ireland & 559 & 131 & 1327 \\
Italy & 11205 & 65 & 1166 \\
Netherlands & 5489 & 125 & 625 \\
Portugal & 476 & 125 & 1218 \\
Spain & 16 & 124 & 235 \\
UK & 19337 & 136 & 4867 \\
\hline
\end{tabular}

Table 5.2: Descriptive Statistics

The variables are defined as follows. The cost of debt is the ratio of the financial expenditures to the outstanding financial liabilities. The variable ASY is the ratio of intangible assets to total assets, LEV is a firm's leverage, Debt is the logarithm of the financial liabilities expressed in EUROS, and ROA is the return on assets. All the statistics are calculated for 1994.

\begin{tabular}{cccc}
\hline & Median & Standard Deviation & \# Obs. \\
\hline Cost of Debt & 0.05 & 89.41 & 74416 \\
ASY & 0.04 & 1.02 & 41672 \\
ROA & 0.03 & 67.28 & 85549 \\
LEV & 0.72 & 0.83 & 84780 \\
Debt & 8.59 & 2.89 & 84309 \\
\hline
\end{tabular}


Firms' balance sheet data are matched with information on the opportunities of risk sharing available in each country. These are in principle difficult to measure. In fact, as Allen and Gale (1995) argue, both market and intermediaries provide opportunities for risk sharing and these are often complementary. To measure the opportunities to share idiosyncratic risk at time $t$, I focus on three measures. These are the capitalizations of the stock and the bond markets to GDP and the share of the three largest banks in the credit market which proxies for the size of financial institutions.

From Table 5.3, it is evident that in my sample different proxies for risk sharing do not create any ambiguity, since according to all the indicators the countries that allow for more risk sharing, because they have more capitalized financial markets or larger financial institutions, are the Netherlands and the UK. In fact, the Netherlands and the UK not only have very developed and well-capitalized financial markets, but have also higher bank concentration as measured by the sum of the credit market shares of the three largest banks.

\subsection{The cost of debt}

To evaluate the impact of financial markets on the cost of capital, one should ideally have a measure of the cost of all the sources of external finance (that is, the interest rate firms pay on debt and the underpricing in the issues of new capital). This comprehends both the issues of new shares and debt. However, in my data set the most of firms are unlisted and there is no measure of underpricing to determine the cost of the issues of new shares. Therefore, I will focus on the cost of debt, which in any case is likely to be the most important source of external funds for a sample of mostly unlisted firms. ${ }^{13}$ Using balance sheet data, the cost of debt can be easily calculated as the ratio of financial expenditures to total debt.

\footnotetext{
${ }^{13}$ However, there is evidence that size has a significant impact on corporate valuation and that this differs across countries. Lins and Servaes (1999) find a negative correlation between size and firm valuation in Germany, but not in Japan and UK. Since Japan and UK have deeper financial markets than Germany and, therefore, offer better opportunities for risk sharing, this finding indirectly supports the results of the model.
} 
Table 5.3: Institutional Variables

The stock (bond) market capitalization is the ratio of the stock (bond) market capitalization to GDP. Bank concentration has been measure by the market share of the three largest banks. All data refer to 1996, end of the year data. Sources: Rajan and Zingales (1999) and Cetorelli and Gambera (2000).

\begin{tabular}{cccc}
\hline & $\begin{array}{c}\text { Stock Market } \\
\text { Capitalization }\end{array}$ & $\begin{array}{c}\text { Bond Market } \\
\text { Capitalization }\end{array}$ & $\begin{array}{c}\text { Bank } \\
\text { Concentration }\end{array}$ \\
\hline Austria & 0.19 & 0.16 & 0.42 \\
Belgium & 0.46 & 0.01 & 0.49 \\
Finland & 0.08 & 0.56 & 0.85 \\
France & 0.39 & 0.11 & 0.28 \\
Germany & 0.35 & 0.59 & 0.27 \\
Ireland & 0.49 & $\mathrm{NA}$ & $\mathrm{NA}$ \\
Italy & 0.21 & 0.03 & 0.24 \\
Netherlands & 0.99 & 0.35 & 0.77 \\
Portugal & 0.23 & 0.06 & 0.46 \\
Spain & 0.43 & 0.02 & 0.34 \\
UK & 1.31 & 0.22 & 0.5 \\
\hline
\end{tabular}


Equation 3.4 predicts that the risk premium increases in the amount of funds provided by a single investor, which is not observed in the data. However, if firms within a country have a homogeneous investor basis, this can be substituted with the total amount of financial liabilities in a firm balance sheet. In countries where investor basis is more limited because of weak institutions, a larger amount of debt is expected to increase its cost, even after controlling for firms characteristics which proxy for the probability of bankruptcy, the extent of asymmetric information problems and the variability and the procyclality of returns. To test whether this implication of the model holds, I estimate an equation where the cost of debt depends on the amount of the outstanding loans (DEBT), and other variables which control for alternative determinants of the cost of debt. ${ }^{14}$ The control variables I include are the variability of returns in the sector and the country of firm $i$ (SROA), which is a measure of firm risk, the ratio of intangible assets to fixed assets (ASY), which is inversely related to the availability of collateral, and the leverage (LEV). The leverage has been included to control that the positive partial correlation between cost of debt and total debt is not spuriously due to the fact that firms with larger outstanding loans are also more levered and, therefore, have higher probability of default that would obviously make their risk premium larger. Since high leverage is correlated with firm defaults only if it is above a certain threshold, I also included a quadratic term for leverage in the equation (LEVSQ). Finally, I included countries fixed effects to control for cross-country differences in the interest rate and 19 sectorial dummies which pick up differences in the cost of funds due differences in systematic risk across sectors.

All the variables with the exception of leverage and the dummy variables have been taken in logarithms. Extreme observations have been excluded and only firms with cost of debt greater than the fifth and lower than the ninety fifth percentile have been included.

\footnotetext{
${ }^{14}$ This exercise is equivalent to the structural estimation of the logarithm of equation 3.4. The only difference is that in the estimated equation the regressor is the aggregate level of debt ( a proxy of $K^{i}$ ) not the investment of each investor $\left(k^{i}\right)$. Therefore, the estimated coefficient is expected to be positive, but smaller than 1.
} 
Table 5.4: The Cost of Debt

The dependent variable is defined as the ratio of the financial expenditures to the outstanding debt. The variable ASY is the ratio of intangible assets to the total fixed assets, LEV is a firm's leverage defined as financial debt to total liabilities, LEVSQ is the square of firm leverage, Debt is the amount of financial liabilities of the firm and SROA is the standard deviation of a firm return on assets. The dummy "High Risk Sharing" is equal to 1 for the UK and the Netherlands and equal to zero for the remaining countries. Country and sectorial fixed effects and a dummy for listed companies have been introduced to control for differences in the cost of funds. Estimates are obtained using a between estimator. The number in parenthesis represents the t-statistics.

\begin{tabular}{|c|c|c|c|}
\hline & $(1)$ & $(2)$ & $\begin{array}{c}(3) \\
\text { Instrumental Variables }\end{array}$ \\
\hline SROA & $\begin{array}{l}0.005 \\
(6.02)^{* * *}\end{array}$ & $\begin{array}{l}0.005 \\
(6.09)^{* * * *}\end{array}$ & $\begin{array}{c}0.006 \\
(6.67)^{* * *}\end{array}$ \\
\hline ASY & $\begin{array}{c}-0.036 \\
(-24.65)^{*+*}\end{array}$ & $\begin{array}{c}-0.035 \\
(-24.43)^{* * *}\end{array}$ & $\frac{-0.035}{(18.86)^{* * *}}$ \\
\hline LEV & $\underset{(1.12)}{0.005}$ & $\begin{array}{l}0.005 \\
(1.10)\end{array}$ & $\begin{array}{l}0.01 \\
(2.23)^{* *}\end{array}$ \\
\hline LEVSQ & $\begin{array}{l}0.0000 \\
(2.01)^{* *}\end{array}$ & $\begin{array}{l}0.0000 \\
(2.00)^{* *}\end{array}$ & $\begin{array}{l}0.000 \\
(2.53)^{\star * *}\end{array}$ \\
\hline Debt & $\begin{array}{c}0.056 \\
(24.22)^{* * *}\end{array}$ & $\begin{array}{c}0.061 \\
(24.91)^{*+*}\end{array}$ & $\begin{array}{l}0.021 \\
(1.66)^{*}\end{array}$ \\
\hline Debt*High Risk sharing & & $\begin{array}{l}0.04 \\
(-6.55)^{+* *}\end{array}$ & $\begin{array}{l}-0.041 \\
(-1.98)^{* *}\end{array}$ \\
\hline No. Firms & 61156 & 61156 & 49747 \\
\hline$R^{2}$ & 0.11 & 0.11 & 0.11 \\
\hline
\end{tabular}

The equation has been estimated using a between estimator that uses individual averages of the variables and ordinary least squares. Since the results were qualitatively invariant, only the estimates obtained with the between estimator are presented.

Results are presented in Table 5.4 and are overall supportive of the conclusions of the model.

Indeed, the cost of debt increases in the amount of outstanding loans. Moreover, if I distinguish the effects of larger demand for loans across countries with 
different possibility of risk sharing (Table 5.4, Column 2), I find that higher outstanding debt has positive and significant effects on the cost of funds especially in countries with less developed financial systems. In fact the coefficient of the variable DEBT interacted with the dummy HIGH RISK SHARING OPPORTUNITIES (which is equal to 1 for the Netherlands and the UK) is negative and significant. This implies that higher dependence on debt increases less the cost of debt in countries where financial markets are more developed. As one would expect, higher variability of returns increases the cost of funds. More surprisingly, firms that lack of collateral have lower cost of debt. Since, as I show later, these firms are also likely to be more financially constrained, this could be interpreted as evidence of credit rationing. As expected, the cost of debt is higher for more levered firms and the quadratic term is always positive and significant. Finally, the country and sectorial dummies were mostly significant.

In alternative specifications (not reported), I also control for the ratio of earnings before interest and taxes to interest expense (EBIT), which is a proxy of the probability of financial distress. As one would expect, a higher value of the ratio of earnings before interest and taxes to interest expense decreases the cost of debt. Most importantly, the estimates of the coefficients of the variables of interest remain qualitatively invariant.

The sign and the significance of the control variables remain unchanged when the variables of interest (DEBT and the interaction are omitted) and the impact of the variables of interest remain qualitatively unchanged in different specification of the equation which in turn have excluded the sectorial dummies and some of the control variables.

As a further robustness check, I estimate the equation for firms with highly concentrated ownership (first shareholder share larger than 75\%) and low concentrated ownership (first shareholder share less than 10\%) separately. While all the results hold for firms with highly concentrated ownership, the impact of the variable DEBT on the cost of funds is not significant for the firms with more dispersed ownership. These firms are likely to have a larger share of market debt 
and therefore more debtholders and are more able to distribute risk among many investors. I also tried to include the share of the first shareholder among the regressors, but the coefficient was always insignificant and did not affect the other estimates.

Finally, I checked for eventual endogeneity problems of the variable debt using a firm's employment as instrumental variable and the results were qualitatively unchanged (Table 5.4, Column 3).

\subsection{The determinants of financing constraints}

This Section implements a further test of the importance of risk sharing for investment decisions by looking at cross-country differences in financial constraints.

Firms with similar investor basis whose demand for external funds is larger should be more financially constrained in countries where there are less opportunities for risk sharing. It is so because the cost of funds is expected to increase faster with the amount of external funds demanded. Since larger optimal scale involves higher need for external funds for young firms which had no time to accumulate internal resources, another testable implication of the model is that financing constraints are expected to be more severe in sectors where firms' optimal scale is larger.

To test the empirical relevance of this implication of the model I need a proxy for the extent of financing constraints and for the optimal firm size, which differs from the actual size because the latter is influenced by the characteristics of the financial system and other distortions due to institutions and resource constraints.

I proxy the optimal firm size by using the data on average firm size by sector taken from the Eurostat' Small and Medium Enterprises database. Size is measured by the number of employees. Notwithstanding these data are based on European firms and, therefore, are influenced by distortions, they provide a proxy for cross-sector differences in optimal firm size. This helps to evaluate the need for risk sharing of firms in different sectors and provides a measure of the demand for risk sharing in a given sector, coherent with the model. 
To measure the extent of financing constraints is a more challenging task. The investment literature suggests that the excess sensitivity of investment to internal sources of funds can be interpreted as evidence of financing constraints (Hubbard, 1998). This is also compatible with the two-period extension of the model.

Therefore, to have an estimate of the extent of financing constraints across countries in accordance with firms' need for risk sharing, I group firms in 19 sectors per country and, afterwards, I estimate the following investment equation using the generalized method of moments: ${ }^{15}$

$$
\frac{I_{t+1 i}}{K_{t+1 i}}=\beta_{0}+\beta_{1} \frac{I_{t i}}{K_{t i}}+\beta_{2}\left(\frac{I_{t i}}{K_{t i}}\right)^{2}+\beta_{3} \frac{X_{t i}}{K_{t i}}+\varepsilon_{t i},
$$

where $I_{t i}$ is the investment at time $t$ of firm $i, K_{t i}$ is the total stock of capital, $X_{t i}$ is the output and $\varepsilon_{t i}$ is a random noise.

The magnitude of the coefficient $\beta_{3}$ is interpreted as a measure of the extent of financing constraints in accordance to the previous literature. Since the ratio of a firm value added to total capital is a measure of productivity at time $t$, if it is very high, current period investment $\left(\frac{I_{t i}}{K_{t i}}\right)$, in the absence of financing constraints, should be larger than future investment $\left(\frac{I_{t+1 i}}{K_{t+1 i}}\right)$. Therefore, $\widehat{\beta}_{3}$ should be negative. However, this variable is positively correlated also with profitability and cash flow. ${ }^{16}$ If firms do not have access to external finance or if its cost increases in the amount of external funds demanded, the estimate of the coefficient $\widehat{\beta}_{3}$ may be positive.

Table 5.5 summarizes a few descriptive statistics about $\widehat{\beta}_{3}$.

To investigate the determinants of financing constraints, I regress $\widehat{\beta}_{3}$ on vari-

\footnotetext{
${ }^{15}$ See Bond and Meghir (1994) for details on the estimation method and the interpretation of coefficients. The previous equation can be derived from the first order conditions of firm intertemporal profit maximization under the assumption that it is costly to adjust investment.

The model presented in this paper can be easily extended to incorporate these assumptions without any changes in the qualitative results.

${ }^{16}$ In the dataset the correlation coefficient between value added and cash flow is larger tha 99 percent.
} 
Table 5.5: Financing constraints: descriptive statistics

\begin{tabular}{cccccc}
\hline & Obs. & Mean & Std. & Min & Max \\
\hline$\widehat{\beta}_{3}$ & 141 & -0.037 & 1.47 & -13.86 & 4.46 \\
\hline
\end{tabular}

ables which measure the extent of information asymmetries, which are often considered a source of financing constraints, the need of risk sharing in a given sector and the supply of risk sharing in a given country.

The supply of risk sharing has been measured by the level of stock market capitalization to GDP. This variable has been interacted with the proxy of optimal firm size in the sector of firm $i$, in order to check if data show a differential impact of an increase in financial development on financing constraints across sectors according to their need of risk sharing. I also controlled for the level of asymmetric information in a given sector measured by the median of the ratio of intangible assets to fixed assets in that sector in a given country.

Results are reported in Table 5.6.

There is a positive, but non significant impact of information asymmetries on financing constraints, measured by $\widehat{\beta}_{3}$. Firms seem to be more financially constrained in sectors and in countries where the median level of employees is larger, but the evidence is weak as the coefficient is significant at $5 \%$ only if the proxy for the extent of information asymmetries is not included. ${ }^{17}$ More interestingly, the coefficient of the interaction variable is negative and significant: financial development seem to mitigate financing constraints more in sectors where firm size is larger. Furthermore, it is important to distinguish across sectors to identify significant effects of financial development, as the model predicts. In fact, the level of stock market capitalization to GDP is not significant if it is not interacted with the average firm size in the sector which measure the demand for

\footnotetext{
${ }^{17}$ The positive relation between actual firm size and the measure of financial constraints could also depend on imperfect competition in the product market. See Bond and Meghir (1994) for details.
} 
Table 5.6: The Determinants of Financing Constraints

The dependent variable is the estimated value of the coefficient of value added, $\widehat{\beta}_{3}$, in the investment equation estimated by sector and by country. In columns 2 and 3 the risk sharing opportunities are proxied by the stock market capitalization to GDP. SROA is the standard deviation of the return on assets.

\begin{tabular}{|c|c|c|c|}
\hline & $(1)$ & $(2)$ & $(3)$ \\
\hline Number of employees & $\begin{array}{c}0.0007 \\
(1.45)\end{array}$ & $\underset{(1.75)}{0.0009}$ & $\underset{(1.08)}{0.0005}$ \\
\hline Intangible assets to total assets & $\begin{array}{c}7.233 \\
(1.58)\end{array}$ & $\begin{array}{l}5.56 \\
(1.04)\end{array}$ & $\begin{array}{l}2.75 \\
(0.58)\end{array}$ \\
\hline SROA & $\underset{(0.13)}{0.000}$ & $\begin{array}{r}-0.000 \\
(0.14)\end{array}$ & $\begin{array}{r}-0.000 \\
(0.58)\end{array}$ \\
\hline Risk Sharing Opportunities & $\begin{array}{l}-0.14 \\
(0.71)\end{array}$ & $\begin{array}{c}0.1 \\
(0.41)\end{array}$ & $\begin{array}{c}0.29 \\
(0.59)\end{array}$ \\
\hline 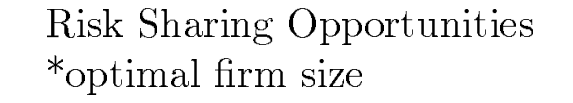 & & $\frac{-0.005}{(-2.33)^{* *}}$ & $\frac{-0.012}{(-1.87)^{*}}$ \\
\hline Obs. & 127 & 127 & 114 \\
\hline$R^{2}$ & 0.03 & 0.09 & 0.06 \\
\hline
\end{tabular}

risk sharing.

I also controlled for the sectorial variability of returns, but the coefficient (estimates not reported) was always not significantly different from zero and the estimate of the coefficient of the variable of interest was not affected.

One of the strongest critiques to this approach is that the current level of cash flow can be correlated with future growth opportunities and therefore the positive correlation between cash flow and investment might depend on reasons which are completely different from financing constraints. To check the robustness of the results, ideally one should control for the market valuation of the assets of a firm. Unfortunately, the dataset does not provide this information since it relies mostly on private firms. Therefore I control for the intertemporal correlation of firm return on assets within a sector: if the current productivity is a good predictor of future productivity, the intertemporal correlation of return on assets should be high. The coefficient of this variable although positive is not significantly 
different from zero. Most importantly, its inclusion does not change the sign and the significance of the variable of interest.

Finally, since it is controversial to interpret the actual magnitude of the coefficient $\widehat{\beta}_{3}$ as a measure of the severity of financing constraints ( see Kaplan and Zingales, 1997), but one can definitively interpret its sign I substituted the dependent variable of the above regressions with $\widehat{\hat{\beta}}_{3}$ defined as follows:

$$
\widehat{\widehat{\beta}}_{3}=\left\{\begin{array}{c}
1 \text { if } \widehat{\beta}_{3}>0 \\
-1 \text { if } \widehat{\beta}_{3}<0
\end{array}\right\} .
$$

The results have been omitted, but remain qualitatively invariant although the significance of the estimates is much lower.

\section{Conclusions}

This paper argues that investor protection and law enforcement may be very important in shaping the industrial structure of a country, as they affect the effort and the resources that are necessary to monitor firms and to enforce contracts. These costs influence the number of firms investors want to finance and, therefore, the opportunities for risk sharing. When risk sharing opportunities are limited, a firm can rely on a small number of financiers. In this case, investors are willing to invest only a limited amount of their resources in firms whose optimal scale is larger, in order not to increase the covariance of their future consumption with the firm's output realization. Therefore, the financial system puts a constraint on firm size.

\section{Appendix}

\section{Proof of Proposition 3.1}

Proposition 3.1 is proved by taking a linear approximation of the marginal utility of final wealth in a neighborhood of its expected value. This is: 


$$
U^{\prime}\left(\widetilde{W}_{1}\right) \cong U^{\prime}\left(\bar{W}_{1}\right)+U^{\prime \prime}\left(\bar{W}_{1}\right) k_{0}^{i}\left(\widetilde{R}_{1}^{i}-\bar{R}_{1}^{i}\right)
$$

Using the linear approximation of $U^{\prime}\left(\widetilde{W}_{1}\right)$, it becomes easy to calculate the risk premium:

$$
E_{0}\left(\widetilde{R}_{1}^{i}\right)=1+\frac{\lambda}{U^{\prime}\left(\bar{W}_{1}\right)}-\frac{U^{\prime \prime}\left(\bar{W}_{1}\right)}{U^{\prime}\left(\bar{W}_{1}\right)} k_{0}^{i} V\left(\widetilde{R}_{1}^{i}\right),
$$

where $V\left(\widetilde{R}_{1}^{i}\right)$ is the variance of the return to investment in firm $i$ and $\lambda=$ 0 if a positive fraction of the initial wealth is invested in the risk free technology (i.e. $\left.\sum_{i} k_{0}^{i} d i<W_{0}-n \tau\right)$. If there is no investment in the risk free asset in equilibrium, the Lagrange multiplier is: $\lambda=U^{\prime}\left(\bar{W}_{1}\right) \sum_{i}\left(\bar{R}_{1}^{i}-1\right) \frac{k_{0}^{i}}{W_{0}-n \tau}$, where $\sum_{i} \bar{R}_{1}^{i} \frac{k_{0}^{i}}{W_{0}-n \tau}$ is the return of the whole portfolio of risky assets.

From equation 6.1 the relationship with the portfolio share of firm $i$ is easily determined: $\frac{d E_{0}\left(\widetilde{R}_{1}^{i}\right)}{d\left(k_{0}^{i}\right)}=-\frac{U^{\prime \prime}\left(\bar{W}_{1}\right)}{U^{\prime}\left(\bar{W}_{1}\right)} V\left(\widetilde{R}_{1}^{i}\right)>0$ and, clearly, implies that the return from investing in firm $i$ is increasing in its portfolio share.

\section{References}

[1] Acemoglu, Daron and Fabrizio Zilibotti (1997), Was Prometheus Unbound by Chance? Risk, Diversification and Growth, Journal of Political Economy, Vol. 105, p.709-51.

[2] Allen, Franklin and Douglas Gale (1995), A welfare comparison of intermediaries and financial markets in Germany and the US, European Economic Review, Vol. 39, p. 179-209.

[3] Angelini, Paolo, R. Di Salvo and Giovanni Ferri, Availability and cost of credit for small businesses: customer relationships and credit cooperatives, Journal of Banking and Finance, Vol. 22, pp. 925-954. 
[4] Banerjee, Abhijit V., Timothy Besley and Timothy W. Guinnane (1994), The neighbor's keeper: the design of a credit cooperative with theory and a test, Quarterly Journal of Economics, vol.109, p. 491-515.

[5] Bond, Stephen and Costas Meghir (1994), Dynamic Investment Models and Firm's Financial Policy, Review of Economic Studies, Vol. 61, p. 197-222.

[6] Burkart, Mike and Fausto Panunzi (2001), Agency Conflicts, Ownership Concentration, and Legal Shareholder Protection, CEPR Discussion Paper No. 2708.

[7] Cerasi, Vittoria and Sonja Daltung (2000), The Optimal Size of a Bank: Costs and Benefis of Diversification, European Economic Review, Vol. 44, p.1701-1726.

[8] Cetorelli, Nicola and Michele Gambera (2001), Banking Market Structure, Financial Dependence and Growth: International Evidence from Industry Data, vol. 56, p. 617-648.

[9] Coval, Joshua and Tobias Moskowitz (1999), Home Bias at Home: Local Equity Preferences in Investor Portfolios, Journal of Finance, Vol. 54, p. 2045-2074.

[10] Davis, Steven J. and John Haltiwanger (1992), Gross Job Creation, Gross Job Destruction, and Employment Reallocation, Quarterly Journal of Economics, Vol.72, p. 819-863.

[11] Diamond, Douglas W. (1984), Financial Intermediation and Delegated Monitoring, Review of Economic Studies, Vol. 51, p. 393-414.

[12] Djankov, Simeon, Caralee MvLiesh, Tatiana Nenova and Andrei Shleifer (2001), Who owns the media?, NBER WP No. 8288.

[13] Geroski, Paul A. (1999), The Growth of Firms in Theory and Practice, CEPR Discussion Paper No. 2092. 
[14] Giannetti, Mariassunta (2000), Do Better Institutions Mitigate Agency Problems? Evidence from Corporate Finance Choices, mimeo, Stockholm School of Economics.

[15] Guiso, Luigi, Michael Haliassos and Tullio Jappelli (2001), Household Portfolios, MTT Press, forthcoming.

[16] Himmelberg, Charles P., R. Glenn Hunbbard and Inessa Love (2000), Investor protection, ownership and investment, mimeo, Columbia University.

[17] Hopenhayn, Hugo A. (1992), Entry, Exit, and Firm Dynamics in Long Run Equilibrium, Econometrica, Vol. 60, p.1127-50.

[18] Kaplan, Steven N. and Luigi Zingales (1997), Do investment-cash flow sensitivities provide useful measures of financing constraints?, Quarterly Journal of Economics, vol. 112 p. 169-213.

[19] Kumar, Krishna B., Raghuram G. Rajan and Luigi Zingales (1999), What determines firm size?, NBER Working Paper No. 7208.

[20] La Porta, Rafael, Florencio Lopez-de-Silanes, Andrei Shleifer and Robert W. Vishny (1997), Legal Determinants of External Finance, Journal of Finance, vol.53, p. 1131-1150.

[21] La Porta, Rafael, Florencio Lopez-de-Silanes, and Andrei Shleifer (1998), Law and Finance, Journal of Political Economy, vol. 106 n.6, p. 1113-1155.

[22] La Porta, Rafael, Florencio Lopez-de-Silanes, and Andrei Shleifer (1999), Investor protection and corporate valuation, NBER WP No. 7403.

[23] Lins, Karl and Henri Servaes (1999), International evidence on the value of corporate diversification, Journal of Finance, Vol.54, p. 2215-2239.

[24] Lucas, Robert E. (1978), On the size distribution of business firms, Bell Journal of Economics, vol. 9 p. 508-523. 
[25] Merton, Robert C. (1987), A simple model of capital market equilibrium with incomplete information, Journal of Finance, Vol 42, p. 483-51.

[26] Moskowitz, Tobias J. and Annette Vissing-Jorgensen (2001), The Equity Premium Puzzle, mimeo, University of Chicago.

[27] Obstfeld, Maurice (1994), Risk Sharing, Global Diversification and Growth, American Economic Review, Vol. 84, p. 1310-1329.

[28] Ongena, Steven and David C. Smith (2000), What Determines the number of bank relationships? Cross-country evidence, Journal of Financial Intermediation, vol. 9 p. 545-550.

[29] Rajan, Raghuram G. and Luigi Zingales (1999), The Politics of Financial Development, mimeo, University of Chicago.

[30] Rajan, Raghuram, Henri Servaes and Luigi Zingales (2000), The cost of diversity: The diversification discount and inefficient investment, Journal of Finance, Vol 55 p. $35-80$.

[31] Ramakrishnan, Ram T. S. and Anjan V. Thakor (1984), Information Reliability and a Theory of Financial Intermediation, Review of Economic Studies, Vol. 51, p. 415-432.

[32] Saint-Paul, Gilles (1992), Technological Choice, Financial Markets and economic development, European Economic Review, Vol.36, p. 763-81.

[33] Shleifer, Andrei and Daniel Wolfenzon (2000), Investor protection and equity markets, NBER Working Paper No. 7974. 